\title{
A STUDY IN
}

\section{WITTGENSTEIN'S TRACTATUS}





\section{A STUDY IN}

\section{WITTGENSTEIN'S}

TRACTATUS

by Alexander Maslow

UNIVERSITY OF CALIFORNIA PRESS

Berkeley and Los Angeles I961 


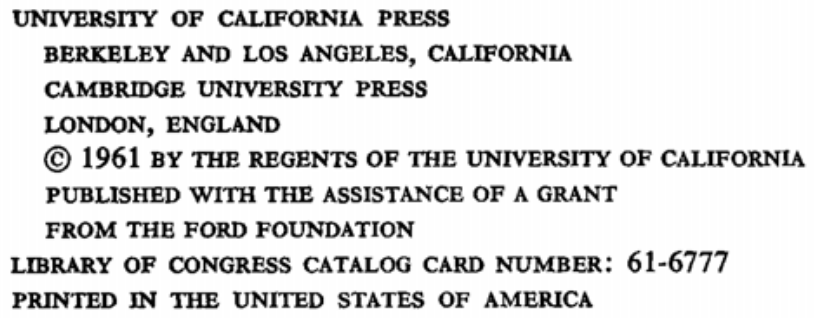


to the MEMory of Moritz Schlick 
